\title{
CHARACTERISTICS, STATUS AND NEED FOR CONSERVATION OF MANGROVE ECOSYSTEMS IN THE REPUBLIC OF MALDIVES, INDIAN OCEAN
}

\author{
AHMED SALEEM ${ }^{1 *}$ \& AMINATH NILEYSHA ${ }^{2}$ \\ ${ }^{1}$ Environment Analyst, \\ ${ }^{2}$ Research Assistant, Environment Research Centre, Ministry of Home Affairs, Housing and \\ Environment, Male, Maldives
}

Proceedings of the South and Central Asian MAB Meeting of Experts on Environmental Conservation, Management and Research, Hikkaduwa, Sri. Lanka 15-18 October 2002

\begin{abstract}
Summary: Very little is known about the wetland ecosystems, particularly mangroves and inland pond ecosystems ( $k u l h i$, faa, chasbin) that occur on the islands of Maldives. It is estimated that 12 per cent of its 1,190 islands have mangrove ecosystems representing 12 true mangrove species. The mangrove ecosystems of the Maldives are unique in that they are not estuarine-based. Biophysical and geomorphological variations are also observed amongst mangrove ecosystems found on different islands. Mangroves are not only considered an important source of food, fuelwood, timber and medicine for Maldivians, but they also act as a buffer against the waves and reduce erosion on islands. The mainstays of the country's economy are fisheries and tourism, both of which are dependent on maintaining a healthy reef system. Mangroves of the Maldives may be pivotal to maintain the rich diversity of life in the marine environment. Despite these, the rapid developmental activities in the atolls are posing overwhelming pressure on these fragile ecosystems. There is enough evidence indicating that they are threatened and rapidly declining on many islands. Formulation and implementation of a mangrove management plan is of utmost importance. Maintenance of these ecosystems is not only important for their ecological and socioeconomic values but also for the sake of protecting the natural and cultural heritage of the Maldives.
\end{abstract}

\section{Introduction}

The Republic of Maldives consists of 1,192 coral islands spread over a distance of $868 \mathrm{~km}$ in a northsouth direction in the Indian Ocean, covering an area of 90,000 $\mathrm{km}^{2}$. India and Sri Lanka are the country's nearest neighbors lying some $600 \mathrm{~km}$ and $750 \mathrm{~km}$ north and northeast of the Maldives, respectively. The islands form 26 natural atolls, which, for purposes of administration, are grouped into 20 units, also called atolls. Most of these low-lying islands are small, with few exceeding an area of one $\mathrm{km}^{2}$. The average elevation of islands is estimated to be only a meter above mean sea level.

The population of Maldives was estimated to be about 270,101 in 2000. This population is scattered over 199 inhabited islands. The remaining islands are

\footnotetext{
" Corresponding author
} 
uninhabited, although 86 of these islands have been developed as tourist resorts. Ninety per cent of the inhabited islands have a population of less than 1,000 and only four islands have more than 4,000 people. Around $26 \%$ of the nation's population live in Male, the capital island.

The climate of the Maldives may be described as tropical monsoon type with two pronounced monsoon seasons. The climate of the Maldives is regulated by the easterly and westerly monsoons. The westerly monsoon, which extends from April to November, brings much of the rain during the year. Monthly variations in rainfall are significant, ranging from $12.3 \mathrm{~mm}$ in February to $250 \mathrm{~mm}$ in May. The annual average rainfall during the period $1995-2000$ was $1,870.3 \mathrm{~mm}$. While there are occasional gales (on average 12 days a year) and tropical thunderstorms (23 days a year), Maldives falls outside the main areas of tropical cyclones. Daily temperatures vary little throughout the year. The annual mean temperature is $28^{\circ} \mathrm{C}$, with a maximum average of about $31^{\circ} \mathrm{C}$ and a minimum of $25^{\circ} \mathrm{C}$. Relative humidity ranges from $73 \%$ to $85 \%$. There are latitudinal changes in the critical environmental factors in the Maldives. For instance, the amount of rainfall increases towards the south, while the effect of storms are more frequent in the north. ${ }^{12}$ Latitudinal variations in geomorphical and geophysical factors are also observed in the islands from the north to the south of the country. ${ }^{1}$

Due to the lack of studies and documentation, little is known about the biodiversity of the Maldives. The major ecosystems of the Maldives include, coastal vegetation, evergreen moist forests, mangroves, and inland pond ecosystems (including kulhi, faa, chasbin) seagrass beds and coral reefs. It has been estimated that in the terrestrial environment, 500 species of higher plants, 2 species of amphibians, 67 species of butterflies, 6 species of reptiles, 5 species of mammals and more than 130 species of insects exist on the islands. Of the estimated 200 species of birds, five have so far been identified to be endemic to the Maldives. The two species of bats found in the Maldives are endemic. The coral reefs of the Maldives are renowned for species diversity and support stocks of endangered species. Some estimates state that 250 species of branching corals, 1,500 species of fish, 5,000 species of mollusks, 200 species of sponges, 1,000 species of crustaceans and 12 species of mammals exist in the marine environment.

\section{Characteristics of Mangrove Ecosystems of the Maldives}

Of the 1,190 islands of the country, mangroves are known to grow on at least 150 of them, which is about 12 per cent of the islands. Elsewhere in the world mangroves are generally found in estuaries. However, this is not the case with the mangroves of the Maldives. There are no freshwater lakes or rivers on the islands. Mangroves on these islands often tend to be found in enclosed or semi-enclosed brackish water bodies locally known as kulhi, or in muddy areas without standing water known as chasbin. The presence of mangrove vegetation on either of the two habitats is referred 
to as faa. The size, shape, composition, and pattern of mangroves vary considerably from island to island. Chaudhury ${ }^{3}$ divided mangrove formations of the Maldives into two broad distinct categories: lagoon-based mangroves and depression-based mangroves. However, it is perhaps more appropriate to classify the mangrove ecosystems as closed systems and open systems (Figure 1). This is exclusively based on the system's exposure to the sea. The closed mangrove systems could be further divided into pond-based inland mangrove systems and non-pond based inland mangrove systems.

\section{Mangrove Ecosystems}

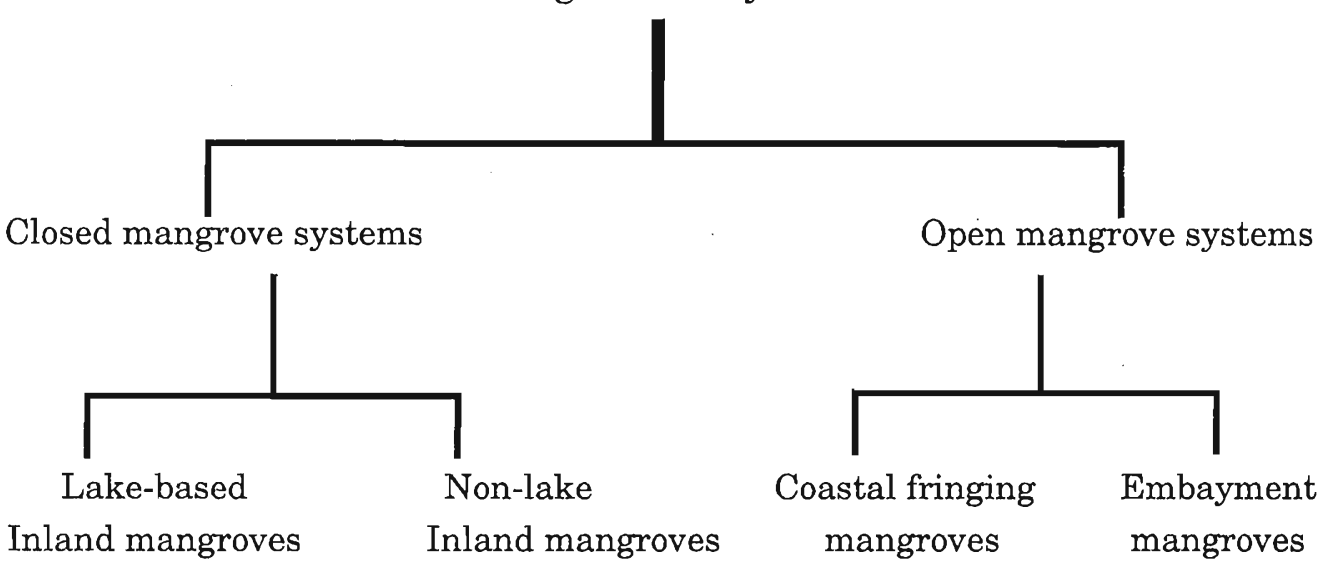

\section{Figure 1: Classification of Mangrove Ecosystems of the Maldives}

Pond-based mangrove: In this case, the mangroves encircle a shallow brackish water pond (kulhi) found on an island (Fuvah Mulah). The depression floor, which is holding the standing water body, consists of forest litter and humus of 4-5 inches. In some cases, the island development processes, perhaps, can explain the formation of such systems. For instance, Hulhudhoo and Meedhoo in Addu Atoll were two separate islands that appear to have joined together with a central depression forming a pond. ${ }^{5}$ However, how mangroves colonise around the pond need further investigation.

Marsh-based mangrove: These mangroves are found on muddy substratum and are not associated with a pond and therefore, are not directly subjected to daily flushing. They grow on part or most of an island depending on the island's surface form. In this case, silt and sand are likely to have accumulated in the depression by runoff, creating the mangrove habitat. The habitat receives saline water through its connections with the sea. ${ }^{3}$ The wetting of the surface may therefore be closely related to the tidal regime. Examples of such mangrove systems are found on Fuvah Mulah and on the Keylakunu Island. 
Similarly, two categories of open mangrove systems have been observed: fringing mangroves and embayment mangroves.

Fringing mangroves: In this case, mangroves are found at the shore and are fully exposed to the sea. The development of a fringing mangrove is likely to be possible only on the sheltered or rubbly coasts. Fringing mangroves are not so common in the country. This may be due to the dynamic nature of the islands' coasts resulting from seasonal and longterm changes. A typical fringing mangrove is found on Goidhoo Island, in Goidhoo Atoll.

Embayment mangroves: This is perhaps the most common mangrove formation in the country, where mangroves partially encircle a 'bay', which is subjected to daily tidal flushing. It is common to see the vegetation forming 'island-like' clumps in such systems. Mangroves of Huraa and Hirimaradhoo (H.Dh. atoll) are examples of this system.

It appears that the formations of closed and open systems are closely related to each other and to the islands' development processes. Shortterm storms may also induce changes to these systems. The process may be faster during the latter process or even spontaneous depending on the magnitude of the storm. The changes that occur to the vegetation structure and the ecology of the system when one transforms to the other may be worth investigating.

\section{The Diversity of Flora and Fauna, and the Extent and Distribution of Mangroves in the Maldives}

Work to inventorise the mangrove species found in the entire archipelago is wanting. The studies carried out by Fosberg in 1949 and by Hackell in 1917 have indicated that only a few species are found in the Maldives. However, Jagtap and Untawala in $1991^{3}$ reported 13 species from 9 genera in the Maldives in 1993. But in 1999 , Jagtap and Untawala reported 12 species of mangroves, belonging to 7 genera, after surveying 19 islands in 4 atolls. In 1995, the Agriculture Ministry of the Maldives reported 8 species of mangroves. Based on some of the above work, at least 14 mangrove species are known to grow in the country (Table 1). Studies undertaken thus far also indicate that the number of species found in any single stand is limited to 4 to 5 species. Mangrove species found in such stands are often found in association with their allies forming thick and healthy vegetation (Table 2).

The South and Southeast Asia region is known to have some of the largest mangroves and the highest diversity of mangroves in the world and the Indo-Malayan region is believed to be the center of origin of the mangroves. ${ }^{11}$ Accordingly, this may be the most likely source of the mangroves species found in the Maldives. Though Maldives is located in a mangrove rich region, lack of long, sheltered coasts and river estuaries have limited the size and the diversity of mangroves. However, 
available data reveals that amongst the island groups of the Indian Ocean, the Maldives Islands appear to host the most number of mangrove species.

Table 1: Mangrove Species of the Maldives

\begin{tabular}{|c|c|c|c|}
\hline Botanical Name & Family & Commen Name & Local Name \\
\hline Avicennia marina & Avicenniaceae & Mangrove & 'Baru’ \\
\hline Bruguiera cylindrica & Rhizophoraceae & Mangrove & 'Kandoo' \\
\hline B. gymnorrhiza & Rhizophoraceae & Mangrove & 'Bodavaki’ \\
\hline Bruguiera sp & Burma & & \\
\hline Ceriops tagal & Rhizophoraceae & Mangrove & 'Kharnana' \\
\hline Derris heterophylla & Fabaceae & & \\
\hline Excoecaria agallocha & Euphorbiaceae & & ‘Thella' \\
\hline Heritiera littoralis & Sterculiaceae & & $\begin{array}{l}\text { 'Kaharuvah' } \\
\text { gas' }\end{array}$ \\
\hline Lumnitzera racemosa & Combreatceae & Black Mangrove & $\begin{array}{l}\text { 'Burevi' } \\
\text { 'Randoo' }\end{array}$ \\
\hline Rhizopora mucronata & Rhizophoraceae & Mangrove & 'Makeha' \\
\hline * Rhizopora sp & Rhizophoraceae & & 'Thakafathi' \\
\hline *Rhizopora $\mathrm{sp}$ & Rhizophoraceae & & \\
\hline Sonneratia caseolaris & Sonneratiaceae & $\begin{array}{l}\text { Crab Apple } \\
\text { Mangrove }\end{array}$ & 'Kulhlhavah' \\
\hline Xylocarpus moluccensis & Meliaceae & Cannonball Tree & 'Maru gas' \\
\hline
\end{tabular}

"One of these is believed to be $R$. apiculata. This was, for the first time, identified in the Maldives during a field visit to Huraa, Male Atoll, by a team from the Environment Research Center on 10/9/2002.

\section{Table 2: Common Mangrove Associates of the Maldives}

\begin{tabular}{llll}
\hline Botanical Name & Family & Common Name & Local Name \\
\hline Tournafortia argentea & Boraginaceae & Tree Heliotrope & 'Boashi' \\
Thespesia populnea & Malvaceae & Milo & 'Hirundhu' \\
Scaevola taccada & Goodeniaceae & Scaevola & 'Magoo' \\
Pandanus sp. & Pandanaceae & Pandanus & 'Kashikeyo' \\
Hibiscus tiliaceous & Malvaceae & Beach Hibiscus & 'Dhiggaa' \\
Pemphis acidula & Lythraceae & Iron Wood & 'Kuredhi' \\
Baringtonia asiatica & Lecythdaceae & Fish Poison Tree & 'Kinbi' \\
\hline
\end{tabular}


The diversity and abundance of fauna found in mangroves vary from island to island. During the surveys of mangrove of the Huraa Island, Male atoll, (a relatively small mangrove) 3 species of reptiles, several species of insects, 10 species of crabs, 4 species of fish, one species of shrimp, and 9 species of birds have been observed (Table 3). Similarly, in islands where the endemic Maldivian Pond Heron (Ardeola graii phillipsi) is found, mangroves are found to be their most important breeding and feeding grounds. The role of the microorganisms is particularly important in the functioning of the mangrove ecosystems. In 1991 Untawala and Jagtap reported 37 species of marine fungi from decayed wood of Maldivian mangroves. A proper investigation of this area is necessary to understand the species and the role of microorganisms in these ecosystems.

Recent surveys undertaken by the Environment Research Centre show that mangrove ecosystems occur mostly in the northernmost and southernmost atolls. They are poorly represented on some and not represented at all on the other atolls of the central region (Figure 2). In the northern atolls, mangroves tend to be found on the islands located on the eastern side of the atoll, while in the southern atolls, mangroves tend to be found mostly on the islands on the western rim of the atoll. Further work in this area is needed to explain this trend. The average size of the mangrove ecosystems and species richness is greater in the north than in the south.

\section{Importance of Mangroves}

Mangroves are important for economic, cultural, social and ecological reasons. Some of the important traditional uses of the mangroves include, use of timber from Bruguiera cylindrica, B. gymnorhiza, Rhizophora mucronata for boat building, construction, firewood, fencing, and the making of fishing poles. The locals consume the fruits of Sonneratia caseolaris and Bruguiera cylindrica. B. cylindrica is also used to make dyes for colouring the fishing lines and its bark is used in indigenous medicine. Direct uses of mangrove ecosystems also include the use of clay from the ponds for pot making in islands such as Kulhudhuffushi. ${ }^{10}$ The ecological services provided by the mangroves are well known. However, no such studies have been undertaken in the Maldives. Accelerated erosion on islands caused by the removal of mangroves clearly indicates their importance for the protection of islands from the sea. By causing sediment to get stuck onto mangrove roots perhaps may not be the only way by which mangroves control erosion. Mangroves also act as barriers against storms and tidal surges. Mangroves are perhaps the single most important grounds for breeding, nesting, and roosting for numerous resident birds of the Maldives. Mangroves are also an important stopover for a large number of birds during their northsouth and vice versa migrations. Mangroves also act as a breeding area for sharks. ${ }^{6}$ They are important nursery areas for larval stages of shrimps and fish species. In addition to several species of finfish, mollusks, crabs and shrimps are commonly found in the mangroves. Mangroves such as Sonneratia and the associate Barringtonia are important food plants for the endemic fruit bat 


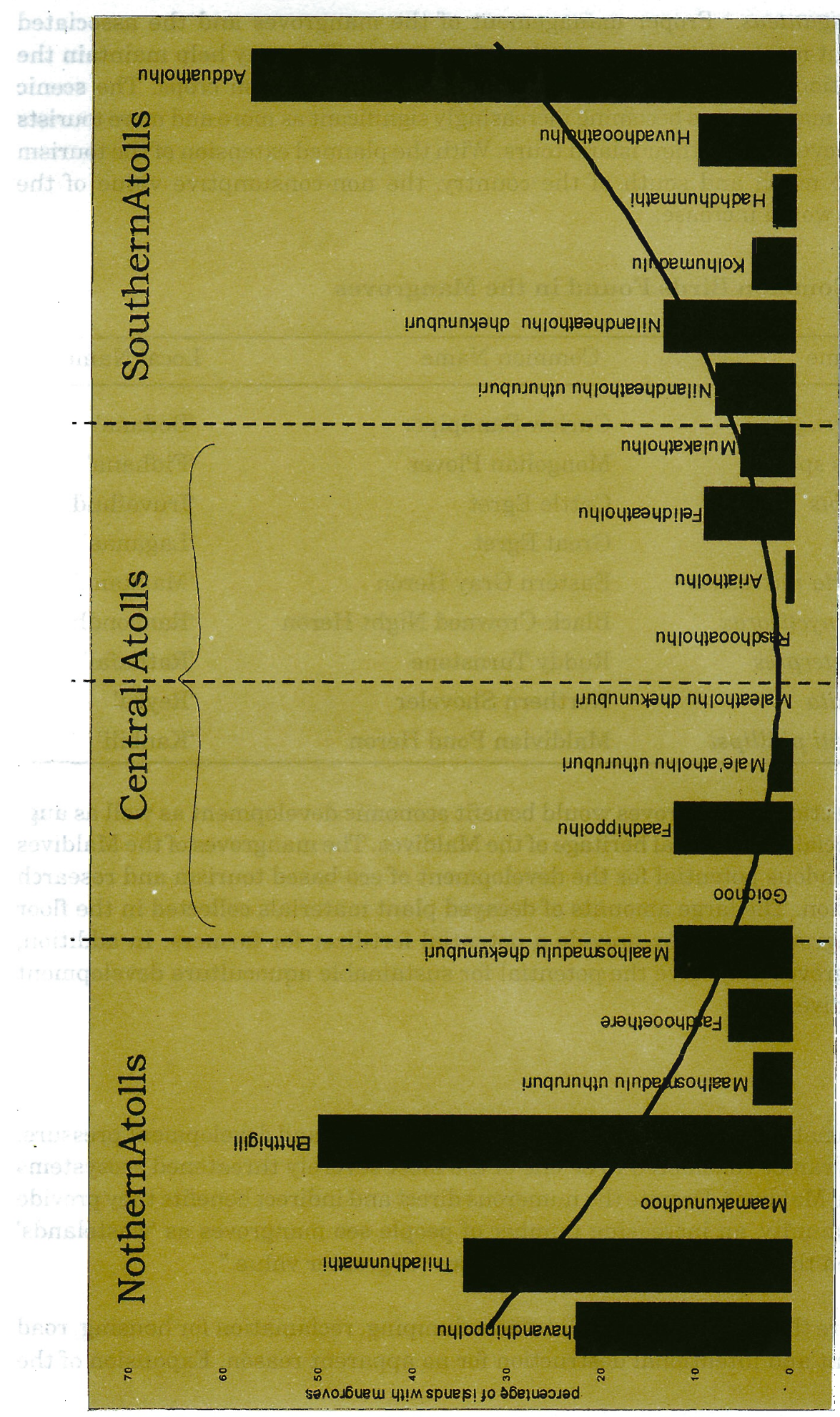


Pteropus giganteus. ${ }^{4}$ Proper management of the mangroves and the associated environment may perhaps increase their food supply. This may help maintain the bat population while trying to deviate their attention on cash crops. The scenic value of the mangroves is becoming increasingly significant as more and more tourists visit mangroves during their island tours. With the planned extension of the tourism zone to the north and south of the country, the non-consumptive value of the mangroves would increase.

Table 3: Common Birds Found in the Mangroves

\begin{tabular}{lll}
\hline Latin Name & Common Name & Local Name \\
\hline Calidris ferruginea & Curlew Sandpiper & 'Bodana' \\
Charadrius sp & Mongolian Plover & 'Fidhana' \\
Bubulcus ibis & Cattle Egret & 'Iruvaihudhu' \\
Ardea alba & Great Egret & 'Laganaa' \\
Ardea cineria rectrostris & Eastern Gray Heron & 'Maakana' \\
Nycticorax nycticorax & Black-Crowned Night Heron & 'Raabondhi' \\
Arenaria interpres & Ruddy Turnstone & 'Rathafai' \\
Anas clypeata & Northern Shoveler & 'Reyru' \\
Ardeola graii phillipsi & Maldivian Pond Heron & 'Kanbili' \\
\hline
\end{tabular}

Protection of mangroves would benefit economic development as well as augment the social and cultural heritage of the Maldives. The mangroves of the Maldives have tremendous potential for the development of eco-based tourism and research and education. The large amounts of decayed plant materials collected in the floor of the mangrove pond may provide a potential fertilizer for farmers. In addition, some mangroves may have the potential for sustainable aquaculture development
in the Maldives.

\section{Threats}

Given the small size, the natural fragility, and population and development pressure, mangroves can be considered to be one of the most severely threatened ecosystems found in the Maldives. Despite the numerous direct and indirect benefits they provide to the community, an increasing number of people see mangroves as 'wastelands' except when they are reclaimed for other uses "of greater value."

Severe threats arise from solid waste dumping, reclamation for housing, road development and intentional destruction for no apparent reason. Expansion of the 
tourism zone is likely to have an impact on mangrove islands in the north and the south.

\section{Ongoing Conservation Activities to Protect Mangroves}

The First National Biodiversity Strategy and Action Plan (NBSAP), 2001, recognized the importance of conservation of the wetland systems, in particular the mangrove ecosystem of the Maldives. In this regard, the following actions have been proposed with regard to the conservation of mangroves:

- Identify mangrove ecosystems important for conservation.

- Develop an economic valuation system for mangrove ecosystems.

- Set aside representative areas of mangrove ecosystems for biodiversity conservation.

- Undertake EIA before commencement of projects that involve mangroves.

- Undertake restoration programmes for ecologically important mangrove ecosystems that are endangered.

- Protect and conserve mangroves wherever possible from being land filled, or being developed without taking conservation into consideration.

Some efforts had been made to study and assess the mangrove ecosystems of the Maldives. The Environment Research Centre of the Ministry of Home Affairs, Housing and Environment is currently conducting research to assess the distribution of mangroves of the country. However, lack of technical expertise and financial resources in the country is hampering the efforts. Despite these difficulties, the government plans to undertake the following activities with regard to the conservation of mangroves in the country.

Establishment of a field gene bank in the Huraa Island (North Male Atoll).

Huraa is one of the two islands on which mangroves are found in the entire Male atoll. It covers an area of 18.8 hectares. The population of the island is about 550 according to the Census of the year 2000. Fishing and tourism are the most important sources of income for the inhabitants. As the island is located in the tourism zone, it is visited by several hundreds of tourists every year eager to experience the Maldivian way of life. One unique aspect of the Huraa Island is its mangroves, which cover almost one half of the island. Residential development occupies the other half of the island. Hence, there is enormous pressure to expand the residential area and to reclaim the mangroves. Huraa, being an inhabited island located in close proximity 
to the capital, Male, and with easy access to the island, is experiencing pressure to develop its public facilities. The island is already hosting a soccer stadium developed with international donor assistance. Other proposed developmental activities include building a Youth Training Centre and Cadet Training Camp on the island. If allowed to proceed with the proposed developmental plan, the island would lose much of its remaining mangroves.

Due to the noticeable decline in mangrove ecosystems of the country and since not all of the species are found in any single island, the government is considering establishing a field gene bank in Huraa to conserve the mangrove genetic diversity of the Maldives. Four species of true mangroves have been identified in Huraa including Bruguiera cylindrica, B. gymnorhiza, Rhizophora apiculata and $R$. mucronata. The government is now considering the bringing about of necessary changes to the proposed land use plan so that the Huraa mangrove ecosystem could be conserved. Depending on the availability of financial assistance, it is also planned to build a narrow walkway around the area to enable visitors to enjoy the beauty of nature while safeguarding the vegetation and the surrounding natural environment. In addition to conserving the genetic resources of mangroves of the Maldives, it is hoped that this would attract more tourists to the island and would contribute to the socioeconomic development of its community. At present an average of 10 tourists visit the island everyday. Almost all the tourists visiting Huraa, take time off to visit its mangroves. ${ }^{9}$

Table 4: Mangroves and its Associates Found in Keylakunu.

\begin{tabular}{lll}
\hline Latin Name & Family & \multicolumn{1}{c}{ Local Name } \\
\hline $\begin{array}{l}\text { Bruguiera gymnorrhiza } \\
\text { B. cylindrica }\end{array}$ & $\begin{array}{l}\text { Rhizophoraceae } \\
\text { Rhizophoraceae }\end{array}$ & $\begin{array}{l}\text { 'Bodavaki / Bodukandoo' } \\
\text { Rhizopora mucronata }\end{array}$ \\
& Rhizophoraceae & $\begin{array}{l}\text { 'Thakafathi / Randoo / } \\
\text { Makeha' }\end{array}$ \\
Avicennia marina & Avicenniaceae & 'Baru' \\
Excoecaria agallocha & Euphorbiaceae & 'Thella' \\
Lumnitzera racemosa & Combretaceae & 'Burevi' \\
Pandanus spp. & Pandanaceae & 'Maakashikeyo' \\
Thespesia populnea & Malvaceae & 'Hirundhu' \\
Hibiscus tiliaceaus & Malvaceae & 'Dhiggaa' \\
Pemphis acidula & Lythraceae & 'Kuredhi' \\
\hline
\end{tabular}


Establishment of a biosphere reserve

Keylakunu Island in H.Dh atoll hosts an extensive Avicennia forest. Large healthy Avicennia forests are perhaps not so common in the world today particularly on island environments. Some of the large trees of Avicennia in Keylakunu measure $100 \mathrm{~cm}$ in diameter at breast height and reaches a height of $15 \mathrm{~m}$. Table 4 summarizes the mangrove species found in Keylakunu. Following the recommendations of the International Society for Mangrove Ecosystems (ISME) and realizing the fact that once destroyed, it would not be possible to regenerate such a forest, the Government is considering declaring the island, together with the adjacent reef area, as the first biosphere reserve.

Table 5 (a): Mangrove Regeneration Activities Conducted in Kulhuduffushi, 2000.

\begin{tabular}{llcc}
\hline Qty & Material & Source & $\begin{array}{c}\text { Percentage } \\
\text { survived/germinated }\end{array}$ \\
\hline 1000 & $\begin{array}{l}\text { propagules \& seedlings of } \\
\text { R. mucronata } \text { and } B .\end{array}$ & H.Dh. Kumundhoo & 70 \\
& gymnorrhiza & H.Dh. Keylakunu & 50 \\
300 & seeds of A. marina & H.Dh. Kumundhoo & 0.6 \\
10 & fruits of $S$. caseolaris & H.Dumd & 1 \\
\hline
\end{tabular}

Table 5(b): Mangrove Regeneration Activities Conducted in Kulhuduffushi, 2001.

\begin{tabular}{llcc}
\hline Qty & Material & Source & $\begin{array}{c}\text { Percentage } \\
\text { survived/germinated }\end{array}$ \\
\hline \multirow{2}{*}{300} & propagules R. mucronata & HA. Baarah & 90 \\
& and B. gymnorrhiza & & 50 \\
200 & seeds of A. marina & H.Dh. Keylakunu & 40 \\
10 & fruits of S. caseolaris & H.Dh. Kumundhoo & 2.5 \\
\hline
\end{tabular}

Table 5(c): Mangrove Regeneration Activities Conducted in Baarah, 2000.

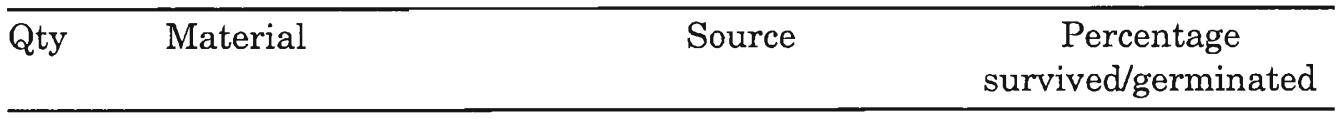

500 propagules of $R$. mucronata H.Dh. Kumundhoo 80 


\section{References}

1 Ali M. (2000). Reef island geomophology: Formation, development and prospectives of islands in Eta Atoll, South Malhosmadulu atoll, the Maldives. Unpublished Ph.D. Thesis, University of New South Wales.

2 Baba S. (2002). Executive Secretary, ISME, Per. comm.

3 Choudry K.J. (1993). Report to the Government of the Republic of Maldives on Mangrove Conservation and Management, FAO, Rome. 79pp.

4 Holmes M., Hutson M. A. \& Morris M.J. (1993). The Maldives Archipelago, Indian Ocean: A report on the investigation of fruit bats and birds. The Bat Conservation Trust. Unpublished Report.

5 Luthfy I. L. (1995), Dhivehiraajjeyge Geograhyge Vanavaru, Male, Maldives.

6 Ministry of Fisheries \& Agriculture (1995). Country Report to the FAO International Technical Conference on Plant Genetic Resources. Maldives Unpublished Report.

7 Ministry of Home Affairs, Housing and Environment, (2001). National Biodiversity Strategy and Action Plan. Ministry of Home Affairs, Housing and Environment, Male, Maldives.

8 Ministry of Planning and National Development (2001). Statistical Year Book of Maldives, Ministry of Planning and National Development, Male, Maldives.

9 Raheem A. (2002). Senior Island Chief, Huraa Island, Per. Comm.

10 Shafeeq A. (1988). Dhivehi Masakkaytherikan, National Centre for Linguistic \& Historical Research, Male, Maldives.

11 Spalding M. D., Blasco F. \& Field C. (Eds.).(1997). World Mangrove Atlas, The International Society for Mangrove Ecosystems, Okinawa, Japan. 178pp.

12 Woodroffe C. D. (1993). Morphology and evolution of reef islands in the Maldives. Proceedings of the Seventh International Coral Reef Symposium 2: 1217-1226. 
Table 5(d): Mangrove Regeneration Activities Conducted in Baarah, 2001.

\begin{tabular}{lllc}
\hline Qty & Material & Source & $\begin{array}{c}\text { Percentage } \\
\text { survived/germinated }\end{array}$ \\
\hline 200 & propagules of . mucronata & Baarah & $\ldots \ldots .$. \\
100 & propagules of C.tagal & Baarah & $\ldots \ldots .$. \\
\hline
\end{tabular}

Based on data provided by Baba, S. 2002.

\section{Experimental plantations}

Experimental plantations and raising nurseries of some mangrove species is underway in Baarah (HA. Atoll) and Kulhudhuffushi (H.dh Atoll). This project is being undertaken by the ISME in collaboration with the Ministry of Home Affairs, Housing and Environment. Under this project, two nurseries were set up in the above islands during September 2000. Work undertaken under this small project is summarized in table 5 (a) to (d). The experimental results will be useful for future mangrove conservation and regeneration activities in the Maldives.

\section{Conclusions}

Mangrove ecosystems of the Maldives occur throughout the country, although they tend to be more concentrated in the northern and the southern atolls. The distinct geographical, topographical, and the geomorphological characteristics of these ecosystems make it unique and different from those found elsewhere in the world. However, rapid developmental activities in the country are posing overwhelming threats to these fragile ecosystems. Conservation of mangroves in the Maldives is further challenged by the lack of technical and financial capabilities in the country, population pressure, the natural vulnerability, the scattered nature and the smallness of these ecosystems. There is, therefore, an urgent need to draw up appropriate strategies and extend the ongoing conservation and management efforts for the management of mangrove ecosystems of the Maldives.

\section{Acknowledgements}

Thanks are due to Dr Mohamed Ali, for going through the draft and the valuable suggestions and improvements made to the text. My thanks are also due to Ms Aminath Nileysha and Ms Hawwa Sithna for the assistance they provided in gathering the appropriate information and data. 